\title{
The Mediator Effect of Logistics Performance Index on the Relation Between Corruption Perception Index and Foreign Trade Volume
}

\author{
Nagehan Uca, PhD candidate \\ Istanbul Commerce University, Turkey \\ Huseyin Ince, PhD \\ Gebze Technical University, Turkey \\ Halefsan Sumen, PhD \\ Maltepe University, Turkey
}

doi: 10.19044/esj.2016.v12n25p37 URL:http://dx.doi.org/10.19044/esj.2016.v12n25p37

\begin{abstract}
Logistics performance of a country plays an important role within both economic and social developments. Therefore examining the relationship among the logistic performance, corruption and foreign trade volume of a country would contribute to the literature. Logistics Performance Index (LPI) has firstly been issued by World Bank in 2007 and continued in the years 2010, 2012, 2014. In this paper the mediator effect of Logistics Performance Index (LPI) on the relation between Corruption Perception Index (CPI) and Foreign Trade Volume (FTV) analyzed for the years 2007, 2010, 2012, 2014. The hierarchical regression analysis method was used in order to determine the mediator effect. As per the analysis results, the mediator effect of LPI on the relation between CPI and FTV is statistically significant. Consequently it could be suggested that the logistics ability of a country trigger the relation between corruption and foreign trade volume.
\end{abstract}

Keywords: Logistics, LPI, Foreign Trade, CPI, FTV

\section{Introduction}

National and international trades are two of the most significant components of logistics sector. Economic indicators are the most important one to understand the improvement and development level of the country. The worldwide sectorial developments have a significant contribution to the production and consumption activities. Within this context; logistics sector has a crucial role both in social and economic development. The scope of the study covers 92 countries data related to Logistics Performance Index, Corruption Perception Index and Foreign Trade Volume (will be lately defined). 
In Turkey; it is very hard to find data about the size of market, number of the firms, turnover, employment generated added value, costs of the logistics sector. When the reports and academic publications of the international institutions are reviewed; it is observed that generally the data related with transportation and communication sector substitutes the logistic sector data. Except this; it is possible to utilize from foreign trade volumes, load traffic and customs records. According to the assessment results depending on EU and USA data; the share of logistics in GDP is around 10\%. Assuming that 2011 GDP of Turkey is 750 billion dollars; the market size of the logistics sector should be over 70 billion dollars in Turkey. In reality; as the turnover of logistics companies are far below these values yet; sector has a big potential both for employment and for investment (Bayraktutan, Tüylüoğlu, \& Özbilgin, 2012). Different assessments are seen about the size of the logistics sector. In Emerging Markets Logistics Index 2014 report of Agility; $72 \%$ of the professionals in the sector stated that the growth in world trade volume and economy will affect the sector (Agility, 2014). In 2013 dated research of Deloitte Turkey on the Logistics Sector ; it was put forward that the growth rates in Logistic sector ( Transportation and communication sector) proceed in parallel with gross domestic product data (Deloitte, 2013). The worldwide potential of the logistics sector is assumed to be 6 trillion dollars. The share of the sector from gross domestic product is between 8 and 10 percent in developed countries. And the sectorial growth over performs with $10 \%$ comparing with the $3-4 \%$ growth rate of world economy. While the employment opportunities in logistics have increased by $5 \%$ in line with the world GDP increase each year ; it increases by $20 \%$ with globalization in logistics market, increase foreign resource utilization, growth of the scales (Logisitcs Sector Report, 2013).

\section{Conceptual Framework}

Logistics performance index is the one that was first issued on 2007 and continues to be issued by The World Bank approximately in each two years as 2010, 2012 and 2014. 2009 LPI was defined on the basis of the surveys, which have been applied approximately to 1000 professionals working for international logistics companies. $45 \%$ of the executives, who participated in the survey, were the ones working in the companies in middle income countries; $10 \%$ were the executives working in the companies in the low income countries and $45 \%$ were the executives working in the companies in high income countries. \%45 of these executives work for big-scale companies; and 55\% work for small and medium-scaled companies. Besides; $35 \%$ of the executives are top level executives, $\% 25$ are site executives, $\% 24$ are department executives and $\% 26$ are low level executives involved in daily activities. (Burmaoğlu, 2012). 
The executives, who participated in the survey, were requested to evaluate the logistics sector in their country using 5-point Likert scale for six dimensions defined below. These can be listed as follows:

1. Efficiency of Customs and Customs Clearance Processes (speed, predictability and simplicity of the processes, ease of transit from the borders, etc.)

2. Quality of the Infrastructure related with Trade and Transportation (ports, railways, highways, information technologies etc.)

3. Competitive Pricing for Shipment

4. Quality and Sufficiency of Logistics Service (logistics companies, customs brokers, etc.)

5. Traceability of the Shipments

6. Timely Delivery of the Shipments to their points of destination. (Arvis, Saslavsky, Ojala, Shepherd, Busch, \& Raj, 2014)

When the indices of the countries are reviewed throughout the years; Sweden, Norway, Luxembourg are defined as the ones that have logistics excellence according to LPI index even if they do not have a busy shipment and delivery traffic. Singapore, Germany and Holland rank permanently on the top. Turkey had a up-and-down score course until 2014; and in 2014, its score dropped down to 3,50 and it decreased to 30th rank. Except this; compared with all neighboring countries, Turkey is the one with the highest LPI score. (Loder, 2014)

Insufficient infrastructure and information technology investments can be shown as the main obstacle against the middle-ranking countries to be ranked on the higher levels of the list. For the countries that are listed on 40th and upper ranks of the list; analysis of the operations and increasing the efficiency is defined as prior target.

LPI is an indicator that consists of the sum of these six performance dimension. The questions, which are not fully answered in the survey used for LPI formation, have been completed with interpolation method. The missing answers have been completed by taking the country average of the answers given to these questions by other people and considering the deviation value of the answers given by the person, whose answers are missing, to the other questions when compared with the country average and these have been assessed in this way. LPI has been created from six dimensions defined by using basic component analysis method. In basic components 'analysis, the average of the answers given by the executives in the country, who participated to the survey, was used. Before applying basic component analysis to the results; data has been standardized by taking sampling averages and dividing them to the standard deviation. The result is the weighted average of the values that have been obtained after LPI basic components analysis (Burmaoğlu, 2012). 
The important aspect of LPI data is that it is in \%80 confidence interval defined for countries 'data. Confidence interval has been used to define the lower and upper limit of the countries LPI results. These results have been defined to indicate that LPI results have been obtained by collecting surveys and there may be sampling mistake. While calculating the confidence interval; standard error of LPI values has been calculated for all the subjects who filled up the survey in each country. The values of the countries have been ranked according to their proximity to upper and lower level. (Arvis, Saslavsky, Ojala, Shepherd, Busch, \& Raj, 2014).

Another variable is Corruption Perception Index (CPI). Countries are ranked according to the level of corruption by means of this index. CPI is a compound index which is prepared by compiling the corruption data obtained from operational reports and experts in several independent and reliable institutions. Index reflects the opinions of the experts including the ones living in the evaluated countries. The target of CPI is to provide data about the corruption perception in the countries. CPI is a compound index that is formed using the researches of businessmen and country analysts. It includes reliable resources that use several sampling frames and different methodologies. Corruption perception that is used in CPI gives information for understanding the actual level of the corruption in relevant country. One of the strong aspects of CPI is that it depends on the concept assuming that by converting the data sources into a single index, the reliability of each individual output increases (Y1lmaz, Kücet, \& Küçük, 2013).

Another data used in this research is the foreign trade volume data. The data is obtained from the reports issued by Ministry of Customs, World Bank Wits Data Base, Unctad Trademap Data Base and Turkish Statistics Institute (TUİK) database.

There are trends in worldwide goods trade which started to emerge in 2013 and 2014; and the effects of which strengthened in 2014; and there are new emerging trends. Most of these trends cause deceleration in goods 'trade in the world. The developments and trends seen in world economy in 2014 directly or indirectly affected the goods 'trade in the world (TIM, 2015). In order to reveal the effects of the changes in total trade volume on supply chain and logistics; foreign trade volume and logistics performance index and corruption perception index have been evaluated together in this study.

Below is the literature review of the studies that have been made on these issues formerly. Marti et al. examined the International trade and LPI with gravity equation in their article named as "The Importance of the Logistics Performance Index in International Trade" which was issued in 2014 (Marti, Puertas, \& Garcia, 2014). In their "Logistics Performance and Export Competitiveness: European Experience" named article; they examined the relation between export competitiveness and LPI on the basis of European 
Union countries (Puertas, Mart1, \& Garcia, 2013). In another study made by the same; they examined the role of LPI in easing trade in developing countries. In their article that was issued in 2015; Pablo Coto-Millán et.al. examined the relation of LPI with Technical efficiency by using stochastic frontier analysis. (Coto-Millán, Fernández, Pesquera, \& Agüeros, 2015). In another article ;Sang-Heui Lee and Jay van Wyk put forward the relation of LPI with other external effects by using structural equation modeling (SEM). (Lee \& Wyk, 2014). Bahaudin et.al. examined the relation between bribery and wealth which based on Corruption Perception Index (CPI) and Gross National Product per Capita (GNP) (Mujtaba, Williamson, Cavico, \& McClelland, 2013). Ewa Lechman examined the relation between foreign trade indicators and global competition index indicators between the years 2000-2011 (Lechman, 2014). Anna Kukla-Gryz examined the International trade indicators by using structural equation modelling (Kukla-Gryz, 2006) .

\section{Research Methods}

In this paper the relationships among the LPI, CPI and FTV has been investigated.

LPI - Logistics performance of a counrty exert crucial influence on corruption perception and foreign trade volume. Because logistics performance is playing critical role in the economy. LPI is an indicator of logistics performance of the countries. LPI consists of the sum of following six performance dimensions:

Customs, infrastructure, ease of arranging shipments, quality of logistics services, tracking and tracing, timeliness. (RYKGM, Connecting to compete 2014 "The Logistics Performance Index and Its Indicators, 2014)

CPI-stands for Corruption Perception Index. This index is compound index which is prepared by compiling the corruption data obtained from operational reports and experts in several independent and reliable institutions. Index reflects the opinions of the experts including the ones living in the evaluated countries. The target of CPI is to provide data about the corruption perception in the countries. CPI is a compound index that is formed using the researches of businessmen and country analysts (Yılmaz, Kücet, \& Küçük, 2013).

FTV - stands for Foreign Trade Volume. Foreign trade volume is total amount of import and export transactions of a country in one year. FTV is an important economic indicator of a country. FTV has relation several indexes such as LPI and CPI.

Main research question of this study is as follows: Does Logistic Performance Index have a mediator role on the effect of Corruption Perception Index on Foreign Trade Volume? (H4) Additionally, following questions have been tried to find answer: Does Corruption Perception Index have a direct 
impact on Logistic Performance? (H1) Does Logistics Performance Index have a direct impact on Foreign Trade Volume? (H2) Does Corruption Perception Index have a direct impact on Foreign Trade Volume? (H3)

In this research, it was suggested that LPI plays the mediator role on the relation between the CPI and FTV. Hypotheses of the research are as follows:

$\mathrm{H}_{1}$ : Corruption Perception Index has a positive effect on Logistic Performance Index Volume

$\mathrm{H}_{2}$ : Logistics Performance Index has a positive effect on Foreign Trade

$\mathrm{H}_{3}$ : Corruption Perception Index has a positive effect on Foreign Trade Volume

$\mathrm{H}_{4}$ : Logistic Performance Index has a mediator role on the effect of Corruption Perception Index on Foreign Trade Volume

Data used in the analysis is secondary data and has been taken from reliable sources. Therefore reliability and validity were not tested and directly came to the phase of hypotheses test.

In order to test $\mathrm{H}_{4}$ hypothesis, hierarchical regression method suggested by Baron and Kenny (1986) was used. They asserted the existence of following conditions in order to prove a variable as mediator: First, change in the independent variable cause the mediator variable to change. Second, change in the mediator variable cause the dependent variable to change. Third, when the mediator and the independent variables are included to the analysis together, the influence of independent variable on dependent variable to decrease or completely disappear (Baron \& Kenny, 1986). $\mathrm{H}_{1}, \mathrm{H}_{2}$ and $\mathrm{H}_{3}$ hypotheses have been tested by means of linear regression analysis. Three models are used. In model $1, \mathrm{H}_{3}$ hypothesis, in model $2, \mathrm{H}_{1}$ hypothesis and in model $3, \mathrm{H}_{2}$ and $\mathrm{H}_{4}$ hypotheses were tested.

The conceptual model of the research was depicted in Figure 1.

Figure 1. Conceptual Model

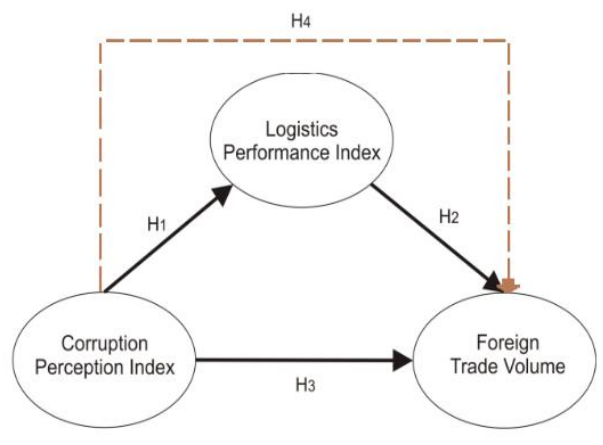




\section{Analyses \& Results}

Prerequisite of the hierarchical regression is the preference of the significant correlation among three variables. Table 2 shows that descriptive statistics and the correlation results among variables according to Pearson correlation coefficient. Correlations are powerful and statistically significant.

Table 2. Descriptive Statistics

\begin{tabular}{|c|c|c|c|c|c|}
\hline \multirow[b]{2}{*}{ Variables } & \multicolumn{3}{|c|}{ Correlations } & \multirow[b]{2}{*}{ Mean } & \multirow[b]{2}{*}{ Std.Deviation } \\
\hline & 1 & 2 & 3 & & \\
\hline 1. CPI & - & - & - & 4,8329 & 2,12432 \\
\hline 2. LPI &, $832^{*}$ & - & - & 3,0746 & 0,55169 \\
\hline 3. $\mathrm{FTV}^{* *}$ &, $359^{*}$ & $486^{*}$ & - & 7,8443 & 0,81374 \\
\hline
\end{tabular}

To test the hypotheses, we performed a series of multiple linear regression models. In the first model, as shown in Table 3, we built the direct relationship model between CPI and FTV. We found that CPI is significantly and positively related to FTV $(\beta=0.359, \mathrm{p}<0.01)$. In second model, we tested the impact of CPI on LPI. We found that CPI is significantly and positively related to LPI $(\beta=0.832, p<0.01)$. In third model, we added the mediating variable (LPI) to the relationship between CPI and FTV. Based on analyses, we found that CPI positively related to LPI $(\beta=0.832, p<0.01)$ and LPI is positively related to FTV $(\beta=0.486, \mathrm{p}<0.01)$, respectively. Of note, the relationship between CPI and FTV vanishes $(\beta=-0.147, p>0.1)$ when we add LPI to the model.

The results of the regression analysis are shown in the Table 3. As shown in Table 3 , difference between $\mathrm{R}^{2}$ value of Model 1 and $\mathrm{R}^{2}$ value of Model 3 was found as 0,114 . F values shows that all the models are generally significant.

Tablo 3. Hypotheses Results

\begin{tabular}{cccc}
\hline Relationship & Model 1 & Model 2 & Model 3 \\
\hline CPI $\rightarrow$ FTV & $0,359^{*}$ & - & $-0,147^{* *}$ \\
CPI $\rightarrow$ LPI & - & $0,832^{*}$ & - \\
LPI $\rightarrow$ FTV & - & - & $0,486^{*}$ \\
\hline R2 & 0,129 & 0,692 & 0,243 \\
Adjusted R2 & 0,126 & 0,691 & 0,238 \\
F & $54,099^{*}$ & $822,329^{*}$ & $58,435^{*}$ \\
\hline & & \\
& & $\mathrm{p}<0.01,{ }^{* *} \mathrm{p}>0.05$
\end{tabular}

According to these results, $\mathrm{H}_{1}, \mathrm{H}_{2}, \mathrm{H}_{3}$ and $\mathrm{H}_{4}$ hypotheses are supported. Therefore the mediator effect of Logistics Performance Index on the relation 
between Corruption Perceptions Index (CPI) and Foreign Trade Volume (FTV) is statistically significant. Consequently it can be suggested that the logistics capacity of a country trigger the relation between corruption and foreign trade.

\section{Conclusion}

In order to show the importance of logistics performance, in this paper the mediator effect of Logistics Performance Index (LPI) on the relation between Foreign Trade Volume and Corruption Perception was investigated. For testing the hypotheses, hierarchical regression method was used.

The result of analyses supported that the mediator effect of LPI on the relation between CPI and FTV is statistically significant. And the results demonstrate there is not significant direct relation between CPI and FTV.

In addition to above mentioned results, CPI has direct effect on LPI. Direct effect of LPI on FTV is statistically significant. After including LPI to the analyses direct effect of CPI on FTV was not observed. This means that LPI plays a mediator role between CPI and FTV. In the current literature, it is argued that logistics performance is an important determinant in increasing the level of foreign trade volume.

\section{References:}

Agility. (2014). Agility Emerging Markets Logistics Index 2014. Transport Intelligence.

Arvis, J.-F., Saslavsky, D., Ojala, L., Shepherd, B., Busch, C., \& Raj, A. (2014). The Logistics Performance Index and Its Indicators. Washington: The Word Bank.

Baron, R. M., \& Kenny, D. (1986). The Moderator-Mediator Variable Distinction in Social PsychologicalThe Moderator-Mediator Variable Distinction in Social Psychological Research: Conceptual, Strategic, and Statistical Considerations. Journal of Personality and Social Psychology, 1173-1182.

Bayraktutan, P. D., Tüylüoğlu, D. D., \& Özbilgin, A. G. (2012). Lojistik Sektöründe Yoğunlaşma Analizi ve Lojistik Gelişmişlik Endeksi:Kocaeli örneği . Uluslararası Alanya İşletme Fakültesi Dergisi, 61-71.

Burmaoğlu, S. (2012). Ulusal İnovasyon Göstergeleri ile Ulusal Lojistik Performansı Arasında İlişki:AB Ülkeleri Üzerine Bir Araştırma . Ege Akademik Bakış, 193-208.

Coto-Millán, P., Fernández, X., Pesquera, M., \& Agüeros, M. (2015). Impact of Logistics on Technical Efficiency of World Production. Springer Science+Business Media.

Deloitte. (2013). The Logistics Industry in Turkey. Deloitte. 
Kukla-Gryz, A. (2006). Use of structural equation modeling to examine the relationships between growth, trade and the environment in developing countries. Sustainable Development.

Lechman, E. (2014). Changing Patterns in the Export of Goods Versus International Competitiveness. A Comparative Analysis for Central-East European Countries in the Period 2000-2011. Comparative Economic Research.

Lee, S.-H., \& Wyk, J. (2014). National institutions and logistic performance: a path analysis. Springer-Verlag Berlin Heidelberg.

Loder. (2014, 3 21). 01 15, 2014 tarihinde Lojistik derneği Web Sitesi: www.loder.org.tr adresinden alınd1

Marti, L., Puertas, R., \& Garcia, L. (2014). The Importance of the Logistics Performance Index in International Trade. Applied Economics, 2982-2992.

Mujtaba, B. G., Williamson, P., Cavico, F., \& McClelland, B. (2013). Managing the Link Between Bribery and Wealth Based on Corruption Perception Index (CPI) and Gross National Product (GNP) per Capita. Journal of Management Policy and Practice.

Müsiad. (2013). Logisitcs Sector Report. İstanbul: Müsiad.

Puertas, R., Mart1, L., \& Garcia, L. (2013). Logistics performance and export competitiveness: European experience. Springer Science+Business Media.

RYKGM, E. A. (2014). Connecting to compete 2014 "The Logistics Performance Index and Its Indicators. Ankara: T.C. Gümrük Bakanlığı.

TIM. (2015). Türkiye İhracatçılar Meclisi Ekonomi Dış Ticaret Raporu. İstanbul.

Yılmaz, Y., Kücet, E., \& Küçük, A. (2013). Uluslararasi Şeffalık Örgütü Yolsuzluk Algılama Endeksi Raporu. Ankara: Başbakanlık Teftiş Kurulu. 